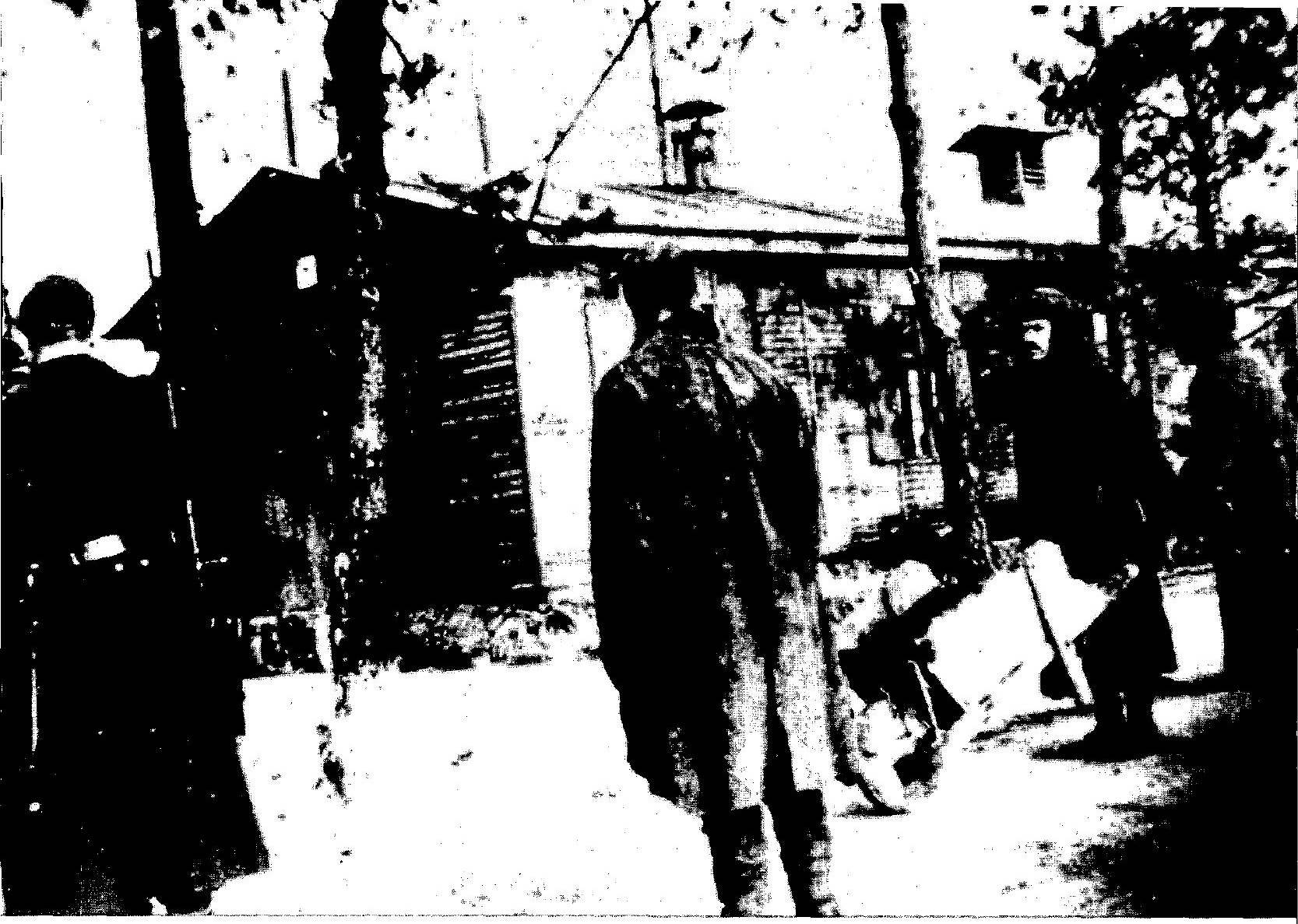

Russische krijgsgevangenen (Archief- en Documentatiecentrum Stichting Erfgoed Eisden) 


\section{Jan Kohlbacher, Het Russisch kamp. De kampen bij de Limburgse mijnen 1942-1965(1)}

Paule Verbruggen, departement Archief AMSAB

Dit boek vertelt het verhaal van de duizenden mensen die tijdens de Tweede Wereldoorlog en in de nasleep ervan al dan niet gedwongen in de barakken rond de mijnen kwamen wonen: de Russische en Duitse krijgsgevangenen, de incivieken en de vele vluchtelingen na de oorlog. De zoektocht naar sporen van dit stukje geschiedenis van de Limburgse mijnen was niet evident, de auteur was er tien jaar mee bezig. Maar zijn 'queeste' loonde: door de vele getuigenissen, brieven en herinneringen kon hij het dagelijkșe leven van de 'kampbewoners' reconstrueren. De emotionele betrokkenheid van de auteur, zelf ex-onderwijzer in de mijncité en zoon van een mijnwerker, is duidelijk voelbaar, maar stoort niet.

De vestiging van de eerste kampen bij de Limburgse mijnen was een logische consequentie van de oorlog en de daaruit voortvloeiende economische toestand. $\mathrm{Na}$ de Duitse bezetting van Europa was steenkool de enige natuurlijke industriële brandstof binnen de grenzen van het Duitse Rijk. Het verwerven van goedkope steenkool uit de onmiddellijke omgeving was dan ook prioritair. De Belgische beleidsmakers van hun kant wilden dat de industrie zo vlug mogelijk tot op een aanvaardbaar peil hersteld werd. Volgens de Galopin-doctrine was handel met de bezetter toegestaan, behalve voor producten die rechtstreeks met de oorlogvoering in verband konden worden gebracht. De export van steenkool naar Duitsland was dus toegelaten en zou voor een deel het tekort, ont- staan door het verlies van de Engelse invoer, opvullen. Aanvankelijk verliep die uitvoer echrer zeer moeizaam en was hij zelfs verlieslatend. Vanaf augustus 1941 ontvingen de mijnen echter een maandelijkse subsidie van dertig miljoen frank. Prangender was echter de dalende productiviteit van de Limburgse mijnen. De oorzaken hiervan waren onder meer de slechtere lichamelijke conditie van de mijnarbeiders door de voedselschaarste en het grote personeelsverloop, onder meer van mijnwerkers die vrijwillig naar Duitsland trokken met de belofte van beter werk en loon.

De - vastgelopen - Operatie Barbarossa tegen de Sovjet-Unie in juni 1941 leidde tot een dramatisch tekort aan steenkool. Kort daarna. kwam de Duitse verordening dat de Belgische steenkoolproductie met $5 \%$ moest opgetrokken worden. Als compensatie beloofden de Duitsers Russische krijgsgevangenen als extra werkkracht naar Limburg te sturen. De mijndirectie was allesbehalve opgezet met dit 'geschenk'. Volgens Kohlbacher speelde hierbij vooral de vrees voor 'besmetting met het commmunistische gedachtengoed'. Onmiddellijk formuleerden de mijndirecteurs het tegenvoorstel om in de plaats van de Russen Belgische krijgsgevangenen in te zetten. In de praktijk kwam dit erop neer dat vooral Walen zouden geëngageerd worden vermits de meeste Vlaamse krijgsgevangenen reeds vrijgelaten waren door bemiddeling van het Vlaams Nationaal Verbond (VNV). In juni 1942 herhaalden de Duitsers hun oproep om te voorzien in geschikte huisvesting, maar nu werd niet meer over Russen als dusdanig gesproken, als wel over mijnwerkers uit de bezette gebieden.

Onmiddellijk werden de eerste barakken gebouwd en afgezet met prikkeldraad. In juli 1942 kwamen de eerste lichtingen "Ostarbeiter" toe. Mensen afkomstig uit de veroverde gebieden uit het Oosten zoals Polen en grote stukken 
van de Sovjet-Unie. De omstandigheden van de rekrutering van die eerste lichting waren niet écht duidelijk. Waren ze gedwongen meegekomen of hadden ze zich vrijwillig opgegeven? De nieuwe groep die vanaf september 1942 over de verschillende mijnzetels werd verspreid bestond wel degelijk uit Russische krijgsgevangenen. In het najaar van 1942 waren de kampen operationeel en werkten er 5301 Russische krijgsgevangen en Ostarbeiter.

De kampen vielen onder de controle van de Wehrmacht, maar de organisatie en het beheer ter plaatse was in handen van de Limburgse mijnzetels zelf. Kohlbacher heeft geen hoge pet op van de manier waarop de mijndirectie de krijgsgevangenen behandelde. $\mathrm{Ze}$ getuigde volgens hem van een echte 'boekhoudersmentaliteit' en probeerde op alles te beknibbelen onder het voorwendsel dat ze geen "liefdadigheidsinstelling zïn": De talloze rapporten van bedrijfsartsen over ondervoeding en zelfs Duitse dreigingen met forse boetes aan het adres van de mijndirectie brachten hierin weinig verandering. Volgens Kohlbacher waren de Duitse ingenieurs hierin zelfs nog consequenter en zagen zij in dat gezonde lichamen beter presteerden. Vraag is of achter die 'consequentere' houding niet een even grote (of nog veel grotere) perversiteit schuilging.

Hoe dan ook, de krijgsgevangenen probeerden op alle manieren hun karige rantsoen aan te vullen. Ze steunden hiervoor op ruilhandel en in mindere mate op hulp van het verzet. Daarnaast konden ze ook extraatjes verwerven in de kantine door een bonussysteem: wie hard werkte kreeg extra rantsoen. Naast de 'ontspanning' in de kantine mochten de gevangenen ook geregeld wandelen of naar de cinema, onder bewaking uiteraard. Toch probeerden vele Russen te vluchten, dikwijls met de hulp van het verzet. Volgens Kohlbacher behoorden ontsnappingen na verloop van tijd zelfs tot de orde van de dag.

Aan het einde van de oorlog, in september 1944, werden de Russische krijgsgevangenen geëvacueerd naar Noord-Duitse kampen. Na hun bevrijding werden ze allen naar de Sovjet-Unie gerepatrieerd. Hun droevige lot is gekend. Volgens Stalin waren allen die het Duitse krijgsgevangenenkamp overleefd hadden collaborateurs. Sommigen kregen de doodstraf, velen moesten naar een werkkamp en een minderheid onderging met zijn familie de 'maatschappelijke uitsluiting'. Een heel kleine groep mijnwerkers had meer geluk: ze bleven anoniem in de Limburgse tuinwijken en meldden zich vrij snel terug aan bij de mijnpoorten. Zij zijn ook meestal in Limburg gebleven...

En wat met de kampen? Zij bleven staan, want het gebrek aan kolen bleef endemisch. De mijnen kampten opnieuw met een dramatische leegloop. Reeds tijdens de oorlog waren er wervingsacties gevoerd om kompels uit MiddenEuropese landen terug naar huis te lokken, een actie die ook na de oorlog doorging. Daarnaast verlieten ook vele Belgen, die mijnarbeid als alternatief voor de verplichte tewerkstelling hadden gekozen, de mijnen. De productiecijfers logen er niet om: in 1938 bedroeg de dagelijkse productie 102.054 ton, in 1944 nog amper 22.000 ton. Het probleem vertaalde zich vrij vlug op het politieke vlak. Achille Van Acker, die naast het premierschap ook het nieuwe kolenministerie leidde, vaardigde een hele reeks maatregelen uit, wat hem de legendarische bijnaam "Achille Charbon" zou opleveren. In de eerste naoorlogse jaren waren de resultaten van zijn campagne nogal pover, het aantal mijnwerkers bleef zelfs dalen. Van Acker probeerde daarop een grote groep 'ontheemden' aan te trekken, namelijk de Duitse krijgsgevangenen. Hij moest daarvoor wel aan de Britten de toestemming vragen voor hun transfer. In mei 1945 brachten de vrachtwagens al de eerste 
groepen Duitsers naar de Limburgse kampen. De krijgsgevangenen die onder Amerikaans bevel stonden werden naar de Waalse mijnen getransfereerd. De capaciteit van de kampen moest, in vergelijking met de oorlogsperiode, op zijn minst verdubbeld, en soms zelfs verdrieof vervijfvoudigd worden. In december 1945 verbleven er 14.385 Duitsers op de mijnterreinen, terwijl het aantal Russen nooit de kaap van de 7000 had overschreden.

De interne organisatie verliep volgens dezelfde schema's als tijdens de Russische periode. In tegenstelling tot de oorlogsperiode werd voor de Duitse krijgsgevangenen wel meer moeite gedaan om enigszins 'normale' levensomstandigheden te creëren, vooral dan door de Young Man's Christian Association (YMCA). Er werden boeken en muziekinstrumenten aangebracht, tentoonstellingen georganiseerd, voetbal- en bokscompetities ingelegd. Toch waren er ook bij de Duitsers veel vluchtpogingen. $\mathrm{Ze}$ waren ook veel mondiger dan hun Russische voorgangers: regelmatig waren er stakingen en sabotage-acties.

Naast Duitse krijgsgevangen werden ook incivieken in de mijnen tewerkgesteld. In brede politieke middens maakte immers het idee opgang dat, wanneer de vroegere vijanden in de mijnen konden worden aan het werk gezet, dit zeker ook voor de "landverraders" mocht gelden. De incivieken zaten wel in kampen die afgescheiden waren van deze van de Duitsers. In 1946 kwamen de eerse berichten in verband met massale repatriëringen van Duitse krijgsgevangenen vanuit de Amerikaanse opvangkampen. In de zomer van 1946 ging de roep van de internationale publieke opinie voor een algemene repatriëring crescendo. De regering van de Verenigde Staten proclameerde een gelijkaardig standpunt en drong er bij Frankrijk, België en Luxemburg op aan alle krijgsgevangenen ten laatste tegen 1 oktober 1947 vrij te laten. De Belgische regering en het mijnpatronaat hielden zich op de vlakte, ze wilden vooral de kolenproductie niet in gevaar brengen. Pas nadat de Belgische Steenkoolfederatie, in maart 1947, 26.000 Italiaanse mijnwerkers rekruteerde, mochten de Duitsers de kampen verlaten. In 1947 waren ook de rangen van de incivieken fel uitgedund. Velen hadden het kamp verlaten omdat ze hun straf hadden uitgezeten. Het kamp van $Z$ wartberg werd als laatste penitentiaire inrichting bij een Limburgse mijn op 31 december 1950 formeel gesloten. Kohlbacher wijst erop dat, net als bij de Russen, de inzet van Duitse krijgsgevangenen en incivieken vooral weer winst opleverde voor het mijnpatronaat en hekelt de Belgische inhaligheid bij de afhandeling van achterstallige lonen en bij de boekhoudkundige afwikkeling van de inzet van krijgsgevangenen.

Nu de Duitse krijgsgevangenen en de incivieken niet meer als goedkope werkkrachten konden ingezet worden, begonnen de mijnmaatschappijen opnieuw naar nieuwe rekruteringsgebieden te zoeken. Vooral Italië leek daarbij een aantrekkelijk gebied. Ook naar het Iberische schiereiland toe werden acties ondernomen, maar met weinig succes. Onder impuls van Achille Van Acker werden eveneens werkkrachten gezochtin de overvolle kampen van de 'displaced persons' of mensen zonder vaderland in de geallieerde bezettingszones van Duitsland. De Amerikanen gingen akkoord, maar eisten voor die mensen een gezinshereniging na drie maanden arbeid.

Opnieuw kregen de kampen een renovatiebeurt. In Eisden werden zeshonderd veertig woonruimtes gecreëerd door het optrekken van bakstenen tussenwanden. Het verloop was er groot. Voor vele families was het kamp een wachtkamer vóór de toewijzing van een huis in de cités, voor anderen slechts een kort en ontgoochelend intermezzo vóór ze naar hun land 
van herkomst terugreisden. Uit het telaas van Kohlbacher blijkt wel dat er een heel aparte sfeer in die kampen heerste en dat zich daar geleidelijk ook een heel intens sociaal leven ontwikkelde.

Naar het einde van de jaren ' 50 toe verslechterde de concurrentiepositie van de Belgische kolenindustrie. Toch bleef het mijnpatronaat vreemde arbeiders aanwerven, vooral Turken en Marokkanen, die weerom gehuisvest werden ... in de kampen. Naarmate de kolencrisis echter dieper werd, stierven ook de kampen uit. Het boek is een boeiend relaas geworden van een bijzonder maar weinig gekend stukje geschiedenis.

(1) Het boek werd ook gerencenseerd door Dirk Luyten in Bijdragen tot de Eigentijdse Geschiedenis, (1999)5, pp. 237-238.

Jan Kohlbacher, Het Russisch kamp, te koop bij

VZW Stichting Erfgoed, Paul Niconlaan 24, 3630

Eisden. Prijs : 650 BEF (excl. verzendingskosten)

\section{Kris Humbeeck, Louis Paul Boon en de fabrieksstad Aalst}

Rik Hemmerijckx, departement Archief $A M S A B$

De meest bekende van Louis Paul Boons romans spelen zich af tegen de achtergrond van de fabrieksstad Aalst of verwijzen impliciet naar de sociaal-politieke toestanden in de stad aan de Dender vanaf het einde van de $19 \mathrm{e}$ eeuw. Zo kennen we vandaag nog steeds de opkomst van de 'socialen', de anarchiserende bende van de Zwarte Hand, of de heroïsche strijd van de sociaal-progressieve priester Daens tegen het katholiek-conservatieve establishment.

Dit betekent uiteraard niet dat Boons werk kan gereduceerd worden tot sociaal-historische romans. Boon was geen historicus, en hoewel hij soms enig opzoekingswerk verrichtte was hij toch vooral een verteller, die de door voorgaande generaties doorgegeven gebeurtenissen en personages in een nieuwe gedaante in zijn romanwereld wist in te passen. De Kapellekensbaan mag wel het prototype genoemd worden van de wijze waarop hij dit procédé heeft toegepast.

De romans van Boon kunnen ongetwijfeld gelezen worden zonder enige historische achtergrond - de opgevoerde figuren zijn als het ware tijdloze karakters geworden - maar dit neemt niet weg dat enige duiding of een korte historische schets niet verhelderend kan werken. Vandaar het belang van een boek als Louis Paul Boon en de fabrieksstad Aalst, geschreven door Kris Humbeeck, één van de Boon-kenners bij uitstek en de drijvende kracht achter het L.P. Boon-Centrum van de Antwerpse UIA.

Het interessante aan dit boek is dat Humbeeck zich niet beperkt heeft tot het schetsen van de opkomst van het industriële Aalst en zijn politiek-sociale strijd, maar dat hij ook oog heeft gehad voor de culturele ontwikkeling. Zo zet hij de betekenis in de verf van Hendrik Conscience "de man die zijn volk leerde lezen". Humbeeck beschouwt Conscience als de tegenpool van L.P. Boon "de man die zijn volk een geweten schopte". Het ganse oeuvre van Boon zou in zekere zin zelfs kunnen gelezen worden als een reactie op het conformisme en romantisme van Conscience. Het kan geen toeval zijn dat één van Boons laatste romans Het Geuzenboek was, terwijl Consciences eerste Nederlandstalige roman een anti-geuzenboek was: In ' $t$ Wonderjaer.

De meest originele bijdrage van het boek schuilt 